59. Roettinger. Hyperemesis gravidarum. (Aertzliche Rundschau, 1894 г., 스 11, стр. 163). Чрезмърная рвота беременныхъ.

Говоря вообще объ этом' забольваніи, автор' подробно ошисываеть свой случай, касаюшійся второбеременной 32 льть, забольвшей рвотой на третьемъ мъсяцঝ беременности. Изъ мъстныхъ патологическихъ явленій у больной были найдены только эрозіи шейки матки, которыя были легко изльчены. Рвота, несмотря на прим'ъненіе многих'ь средст'ь, продолжалась и втеченіе трехт мъсяцевъ крайне истощила больную. Больная (нервная женцина, съ нервною, психопатическою насльдственностью) наqала жаловаться на сокращенія кишекъ и желудка въ обратномъ направленіи (rückwärts). Тогда авторъ, давъ больной опійной настойки, внушиль ей, что у нея ощущенія обратнаго движенія кишекъ и желудка и. рвота прекратятся. Рвота шрекратилась безвозвратно, и беременность опончилась впосл'цствіи правильно двумя доношенными мальчиками. Сопоставляя свой случай съ наблюденіями C. Хазана (Cntrlbl. f. Gynäk., 1887 г.), Kaltenbach'a, Muret (Deutsche med. Wochenschr., 1893 г.) и цруг., авторъ прихоцить къ заключенію, что чрезмьрная рвота беременныхъ есть психоневрозъ, развивающійся на соотвътствующей цочвъ (у женщинъ съ извћстнымъ предрасположеніем'ь) подъ вліяніемъ различныхъ соматическихъ причинъ: иск: ивленій матки, растяженій ея полости, желудочно-кипечныхъ разстройствъ и проч.

\title{
Н. Какушкинь.
}

60. Konikow. Zur Lehre von der Entwickelung des Beckens und seiner geschlechtlichen Differenzirung. (Archiv für Gynaekologie, Bd. XLV, Hft. 1). Къ учөнію о развитіи таза п его дифференцировки въ завискмости оть пола.

Авторъ дълаеть первую попытку не умозрительнымъ, а эмпирическимъ шутемъ разръшить спорный вопросъ о томъ, какіе моменты обусловливають собою форму костнаго таза. Произведенныя имъ съ этою цьлью систематическія наружныя измьренія таза у 120 индивидуумовъ обоего пола и всьхъ возрастовъ отъ одного года до двадцати лътъ, привели къ сльдующимъ результатамъ. На развитіе формы таза всегда вліяють одновременно нъсколько факторовъ, стешень дыъйствія которыхъ однако ве всегда одинакова, такъ что въ каждомъ данномъ возрасть удается уловить преобладающее вліявіе одного изъ нихъ. Такъ, впродолженіи

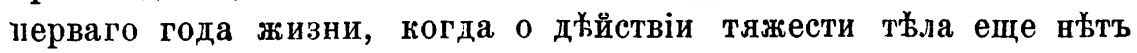
рћчи, рость костнаго таза происходитъ исключительно въ силу 
врожденной энергіи; всльдствіе чего увеличепіе размъьровъ таза въ этой эпохж жизни относительно самое большое и, что главное, равномьјное во всьхт діаметрах'ь. Въ посльдующіе 4 года жизни особенно ощутительно сказывается вліяніе тяжести ть'ла; и цъйствительно, въ әто время зимтчается относительно малое јвеличеніе conj. ext. въ сравненіи съ поперечными діаметрами таза. Наконепъ, съ 10-11 года наqинается дифференцировка таза. Зенсскій тазъ, сообразно своему будущему назиачепіг, постепенно становится во всћх' діаметрахь больше мужскаго, достигая максимума въ этонь отноненіи около 15 года, когда виервые иробуждается специфическая дьвятельность половыхъ органовъ. Мужской же тазъ только около 20 года жизни достигаеть величины женскато таза и то лишь въ поперечныхь діаметрахь, тогца какь conj. ext. навсегда остается въ немъ короче, чймъ въ женскомъ.

Хазанг.

61. Krohl. Klinische Beobachtungen über die Einwirkung einzelner Mutterkornpräparate (speciell des Cornutin) auf den Verlauf des Wochenbettes. (Archiv für Gynaekologie, Bd. XLV, Hft. 1). Кллиническія наблюденія надъ дъ̌йствіемъ нъкоторыхъ препаратовъ изъ Secale cornutum, спещ. корнутина, на теченіе родильнаго періода.

Произведя сравнительныя наблюденія на пъиломъ рядљ, въ одинаково благопріятныхъ условіяхь находящихся, родильницъ, изъ которыхъ однб не получали ничего, другія-эрготинъ, а третія наконецъ,-cornutin-Kobert ( $8 \mathrm{mg}$. pro dosi-2 cg. pro die), K. могъ убъдиться въ несомнънномь дыйствіи этого-посльдняго средствана скорьйшее обратное развитіе матки. Такимъ образомъ еще разъ подтвердилось, установленное уже другими авторами, мнъніе

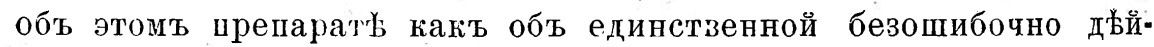
ствующей составной части маточныхт рожковъ.

Позаимствуемь изъ этой работы нысколько практическихъ данных' относительно cornutin'a:

1) Корнутинь содержится, по Коберту и Грияфельду, въ маточныхъ рожкахъ въ достаточно дыйствующемъ количествъ лишь въ первые мйсяды посль жатвы. Уже 1/4 года спустя содержаніе корнутина въ рожкахъ начинаеть уменьшаться, такъ ч'го въ весенніе мъсяцы маточные рожки всльдсствіе почти полнаго отсутствія въ нихъ корнутина совершенно теряють свое дййствіе.

2) Въ препаратахъ, получаемыхъ ивъ маточныхъ рожковъ, cornutin содержится преимущественно въ эрготин年 Bombelon'a и Denzel'a. 